\title{
Modeling learning situations of verbal communication in professionally- oriented teaching English for students in the sphere of transport logistics
}

\author{
Aigul Y. Niyazova - Alma K. Mussagozhina - Ayazhan B. Kabdenova - \\ Assylzada E. Lukpanova - Madina T. Kozhakanova
}

DOI: 10.18355/XL.2018.11.02.15

\begin{abstract}
The article is devoted to the practical training of high school students in the field of transport logistics in everyday speech and the language of the non-linguistic specialty for the active use of a foreign language, both in everyday and in professional verbal communication, which is one of the leading indicators of education and competitiveness in the modern labor market. As the main task in teaching professionally-oriented English language in the context of multilingualism, the leading integrative communicative method is considered. It serves as verbal communication, and its purpose is the formation of communicative competence first of all. This method contributes to the creation of the main model of teaching professionally-oriented verbal speech in English. Modeling situations of professional verbal communication is designed to prepare students for the real conditions of the future profession. Speech situation is defined in the methodology as a set of circumstances in which verbal communication is realized, a system of speech conditions that are necessary and sufficient for performing a speech action. To achieve the set goal of training - forming the skills and abilities of professionallyoriented verbal communication in English of the future engineers of transport specialties a teaching methodology was developed. This methodology is based on the integrative model of training for professional verbal communication of transport workers, consisting of five modules: target, subject-content, conceptual, organizational-activity and control-result and is based on modeling situations of verbal communication. Under the level of language proficiency, as we determined professional-sufficient level, we understand a certain degree of development of the communicative competence of a specialist, necessary for solving professional problems in terms of the effectiveness of using language knowledge, speech skills and abilities. The mentioned levels are characterized by a different degree of formation of communicative skills; the quality of the statement (volume of the statement, degree of complexity, variety of language tools used, relevance of the language tools used, accuracy of transmitted / understood information); fluency of speech, a degree of confidence and independence in the process of communication. The method of teaching professionally-oriented verbal communication of students of transport specialties assumes its use in engineering colleges in other technical higher educational institutions, as well as at the senior stage of training in secondary vocational schools for the training of transport logistics specialists.
\end{abstract}

Key words: professional-oriented teaching, verbal communication, modeling situations of verbal communication, communicative competence, transport logistics

\section{Introduction}

As things stand, Kazakhstan identified a number of priority technical specialties, which are the main factors for stimulating economic development. In modern conditions, a key role for the country's industrial development is given to transport logistics, since all freight traffic in Kazakhstan and the goods delivered from Kazakhstan depend on the correct logistics schemes. Kazakhstan, being at the junction of international corridors, has all the prerequisites to become the main logistics link connecting Europe and Asia. As our observations and research results show, seventy 
per cents of the information for our country comes from Europe in English, so providing a communicatively-necessary level of proficiency in a professionallyoriented foreign language for young graduates of this field is extremely efficient.

Foreign language training of transport students of the non-linguistic specialties in our country is carried out in two stages. At the first stage, it is aimed primarily at solving general educational problems ("Foreign Language"), and at the second stage, it is aimed at solving special professional problems ("Language for Specific Purposes"). They differ in the subject matter and lexical vocabulary of the text, the priority of a particular type of speech activity, the development of the skills necessary to master the appropriate feature of speech. However, despite the number of hours assigned to the foreign language discipline and the good technical base of the university (simulators, multimedia programs) in teaching students to professionally oriented verbal communication, teachers face difficulties due to the lack of developed teaching methods for foreign-language verbal communication in the context of professional activity of transport workers with use in the educational process of the specified technical means in the conditions of specially modelled educational environment. However, the university course of the foreign language at the same time cannot provide for all spheres of professional verbal communication of this specialty (Arpabekov, Suleimenov, 2012; Birova, Vasbieva, Masalimova, 2017; Li, Pyrkova, Ryabova, 2017).

The results of questioning and interviewing of teachers at the university on the training of transport logistics engineers show that often the level of possession of oral professional verbal communication in English by the graduates does not ensure their readiness for effective communication by verbal means within the acquired specialty. Specificity of teaching professionally-oriented verbal speech in higher education gives the future specialist the possibility of using a foreign language not only as a means of obtaining information but also as a means of communication. Therefore, the goal of professionally-oriented learning can be formulated as the formation of a professional foreign-language communicative competence that allows students to professionally communicate using verbal means of speech in various communicative situations.

The hypothesis of the current study is following: if the training of professionallyoriented verbal communication of students in transport specialties will be built on the basis of the designed integrative model, then the effectiveness of teaching this type of communication will increase. Also, the following research questions are put:

1. Is the designed model of professional verbal communication suitable for students of transport specialties?

2. Does the model allow to optimize and intensify learning process of verbal communication for half an academic year?

3. Is this model convenient for teachers to prepare exercises?

\section{Literature Review}

\subsection{Communicative Competence of the Future Specialist in the Context of Modern Higher Education in the Field Of Transport Logistics}

In the requirements to the conditions for the implementation of the basic educational programs for training specialists, it appears that the implementation of the competence approach should provide for the extensive use in the educational process of active and interactive forms of conducting classes (business and role games, case studies, combined with extracurricular work in order to form and develop professional skills, and teaching with computer simulations) (Makulova, Alimzhanova, Bekturganova, 2015; Gakushkin, 2017a,b). The course of teaching foreign languages in the university has a communicatively oriented and professionally directed character and leads to the formation of communicative competence among students, which makes it possible to use the language practically in professional activity (Kunanbayeva, 2016).

XLinguae, Volume 11, Issue 2, April 2018, ISSN 1337-8384, eISSN 2453-711X 
Communicative teaching of foreign languages is teaching organized on the basis of assignments of a communicative nature, which is aimed at mastering students, first of all, with the skills of foreign-language communication (Fahrutdinova, Fahrutdinov, Yusupov, 2016). In order to master these skills, we will analyze communicative competence in more detail. Communicative competence is the knowledge, skills and abilities necessary to understand others and generate their own speech behavior programs, adequate goals, spheres, communication situations, the ability formed in the interaction of a person with a social environment in the process of acquiring sociocommunicative experience (Azimov, Shukin, 1999; Galskova, 2004; Gez, 1985; Zimnyaya, 2004; Passov, 1991; Hymes, 1992). In our research work, we focus on communicative competence stimulating the development of verbal means of communication of future specialists in the field of transport logistics.

Studying the state programs, the literature (Griffiths, 2011; Agbatogun, 2014; Cañado, 2013; Masalimova, Ivanov, 2016; Liton, 2015) as well as the results of scientific experiments, we highlight a number of key bachelor's skills in transport for competent solution of professional tasks: being able to use knowledge of a foreign language in professional and interpersonal communication; the ability to correctly use professional vocabulary and sustainable speech of transport workers; the ability to understand and send information in English: a) transport operation; b) technical service; c) repair of equipment in certain situations of professional activity; abilities to request information and to ask again. In our study, in order to achieve one of the goals, the formation, and development of communicative competence, we relied on the listed skills and abilities of future transport specialists.

\subsection{Characteristics of Verbal Communication as a Means of Speech Interaction}

A modern professional-oriented approach to teaching a foreign language presupposes the formation of the ability of students verbal communication in specific professional, business, scientific spheres and situations, taking into account the peculiarities of professional thinking, with the organization of motivationalstimulating and research-oriented activities.

The process of teaching foreign speech seems to be a complex pedagogical activity, consisting of two methodologically diverse tasks: communication of language knowledge and the formation of speech skills and abilities (Leontyev, 2003). Message of language knowledge implies teaching foreign language material, that is, teaching verbal communication. The formation of speech skills is the teaching of the process of verbal communication by means of the foreign language, i.e. training of speech activity. Verbal communication is considered as the main form of social and communicative activity based on the use of appropriate verbal means. This is a form of realization of the process of interaction of people, carried out through the language as a system of units and the rules of their operation and revealed in the speech activity of communicants (Zimnyaya, 1985).

Professionally-oriented verbal communication in a foreign language is a kind of communication aimed at exchanging professionally relevant information. Such information is subject to transfer, storage, and reproduction. At the same time in the process of exchange, interactive learning and mutual understanding between communication partners, that means representatives of various professional communities, play an important role. When teaching professionally-oriented verbal communication, the principle of speech orientation presupposes the active participation of students in professionally-oriented speaking, and accordingly, the quality of exercises oriented toward the formation of speaking skills becomes an important aspect. The use of specific terms should be justified by considerations of communicative value for the professionally-oriented speech of students, and the basis for communicative learning is the problematic situation. In our context, the problematic situation is the professional orientation of speech and situations (Makar, 2000). 


\subsection{Peculiarities of Modeling Situations of Professional Verbal Communication in a Technical Specialty}

The basis of speech generation is the motive, i.e. intent of the speaker to participate in the verbal communication. The act of verbal communication arises against the background and under the influence of the totality of circumstances affecting a person, always occurs in a specific situation that facilitates the emergence of the motive to come into contact. The dictionary of methodological terms defines the situation as a system of external conditions relative to a person, a fragment of reality that prompts it to perform actions (Azimov, Shukin, 1999). Communicative orientation of the foreign language course in non-linguistic specialties suggests that the learning process is built as a model of the communication process, and the speech situation acts as a determinant of the content and forms of verbal communication, the form of the functioning of interaction and the unit of communication (Vaisburd, 2001; Passov, Stoyanovsky, 1989).

The role of learning and speech situations (later LSS) in mastering a foreign language, in revealing the practical potential of this subject and its educational and developmental functions are defined as follows:

1) Learning situations model fragments of objective reality, correlated with the speech actions of the partners in communication.

2) LSS provide an opportunity: a) to show clearly where, when, for the solution of what communication tasks it is possible to use the presented and assimilated material; b) to ensure the personal participation of everyone in listening and the use of the material being processed in the statements.

3) The learning situation should cause the trainees to have a certain emotional state, interest, the desire to engage in communication, the willingness to participate in it, and help to better recognize each other (Rogova, 1984).

It is obvious that in teaching professionally oriented verbal communication of students of a non-linguistic specialty it is necessary to model professionally oriented speech situations that imply a system of created conditions and interrelationships of interlocutors aimed at achieving a communicative task through professional speech actions developing professional and communicative skills (Temnikova, Osiyanova, Tuchkova, 2016). In its turn, the term "model" is treated in modern science as a specially created form of an object for the reproduction of certain characteristics of an authentic object that is to be cognized (Arhangelsky, 1980). According to M. Knowles, E. Holton, R. Swanson (2005), the content pedagogical model is directly related to the translation of information and skills, and the procedural model, helps to acquire information and skills and is associated with providing procedures and resources that help students to master information and skills. The main difference between the procedural model and other types is that the teacher (facilitator, consultant) prepares in advance a set of procedures for involving students or other relevant groups in the learning process. In our understanding, the design of a model of professional verbal communication is a procedural model.

As for the term "modeling", it can be regarded as a scientific method of researching all sorts of objects, processes by constructing their models, which preserve the basic distinguished features of the object of investigation (Arhangelsky, 1980). Modeling situations of verbal communication during the process of teaching verbal communication in a foreign language in a non-linguistic specialty can be applied at different stages. They contribute to the development of oral and written skills, expand the vocabulary and linguistic horizons of students (Kosogova, 2014). It should be borne in mind that the construction of training models should be based on the limitations imposed on the parameters inherent in the speech situation, taking into account the goals, objectives, and conditions of training, in our case, in the technical specialty. Modeling the situation of verbal communication in the educational process,

XLinguae, Volume 11, Issue 2, April 2018, ISSN 1337-8384, eISSN 2453-711X 
it is necessary to proceed both from the features of modeling and the modeled subject, and from the specifics of the learning process (Vaisburd, 2001).

When modeling situations of professional verbal communication of future transport workers, the following features are taken into account:

a) linguistic (the topic or subject of the message, professional vocabulary, terms, chunk of language with regard to programs);

b) didactic-methodological (organization, availability of visual aids: graphs, diagrams, simulators);

c) psychological (professional motive stimulating to speech action, professional interests, individual peculiaritiess of students);

d) professional (the context of professional activity: the circumstances of reality, conditions, participants in communication and relations between them).

Considering the theoretical aspects related to the issue of teaching professionally oriented verbal communication of students in the specialty of transport logistics, we turn to the development of an integrative model of verbal communication that will contribute to the achievement of the goal of training - the formation of the ability and readiness of students for professionally oriented verbal communication in English. The integrative model proposed by us is built from the setting of the goal of teaching to the achievement of the result of teaching. Thus, the model developed by us consists of five blocks: target, subject-content, conceptual, organizational-activity, and control- result.

Based on the levels of foreign language proficiency in accordance with the requirements of the state programs, which imply the achievement of the third (threshold) level B1 (Bogatyreva, 1997), and also taking into account the field of our research - professionally oriented verbal communication of students of transport specialties, to achieve the communicative goal of education, we highlight professionally-sufficient level in mastering the English language of transport specialists. The professionally-sufficient level presupposes the ability of a specialist to receive and transmit professional information in the foreign language in specific communicative conditions to solve a limited number of communicative tasks. At this level, a number of mistakes are allowed in speech, which does not interfere with the correct understanding of the message.

The level of proficiency in a foreign language in situations of professional activity is an indicator of the achievement of the communicative goal of teaching language at a university. The result of the training is the given level of the formation of the skills of professionally-oriented verbal communication in English of students of transport specialties.

After consideration of the target and control-result blocks of the proposed model, we must answer the question: how to get the planned result based on the goal. The subject-content, conceptual and organizational-activity blocks allow us to reveal the essence of the investigation process.

The subject-content block includes the components of the content of training for professionally oriented verbal communication of students of transport specialties determined in view of the professional orientation. Principles of training are the basic starting points of the teaching of the foreign language in non-linguistic specialties, the integrated implementation of which ensures the effectiveness of the learning process constitute a conceptual block.

Organizational-activity block reflects the process of forming abilities and developing the skills of professionally oriented verbal communication and involves defining strategies for achieving the goal of teaching as the main ways to acquire, preserve and use knowledge about the system of language and speech abilities and skills realized in methods and methodical ways through the system of exercises (Stukalina, 2014; Kavanagh, 2007).

Task on the "Packaging and labelling" topic 
Students make up a dialogue and role play the situation.

S 1. You are a representative of Sales Department at Sony Corp. Your task is to inform the transportation manager about the features of AIBO pet-robot. Discuss possible damages while transporting. Decide upon the most appropriate package.

$\mathrm{S}$ 2. You are a transportation manager at BestLogistics. Your task is to give professional information on suitable types of protective packaging for AIBO petrobot. Discuss possible damages while transporting. Decide upon the most appropriate package.

After a certain period of work in such situations, students form an orientational basis of speech actions, that creates conditions in which with the gradual removal of the semantic supports expressed by linguistic means students themselves are able to create them.

The study revealed that the goal of teaching professionally oriented verbal communication of students in transport specialties is achieved by implementing in the learning process a strategy of simulative communication in the following components (Elukhina, 1995):

1) simulation based on learning and speech situations;

2) ICT-based simulations.

And also the strategy of real communication and its components:

1) verbal communication on the basis of real professional situations in the classroom;

2) real professional communication.

Table 1: Correlation of the stages of work on the topic with the types of exercises and the process of formation and development of skills and abilities

\begin{tabular}{|l|l|l|}
\hline $\begin{array}{l}\text { Stages of work on the } \\
\text { topic }\end{array}$ & Type of exercises & Skills and abilities \\
\hline Information-analytical & Pre-communicative & $\begin{array}{l}\text { Formation and training of } \\
\text { speech skills and abilities }\end{array}$ \\
\hline Training-reproductive & $\begin{array}{l}\text { Conditionally } \\
\text { communicative }\end{array}$ & $\begin{array}{l}\text { Formation and } \\
\text { improvement of speech } \\
\text { skills and abilities }\end{array}$ \\
\hline Productive-creative & Authentic-communicative & $\begin{array}{l}\text { Development of } \\
\text { professionally oriented } \\
\text { verbal communication } \\
\text { skills and abilities }\end{array}$ \\
\hline
\end{tabular}

The process of teaching professionally oriented verbal communication of students of transport specialties is carried out on the basis of textual material of a professional orientation within a specific topic in three stages (Table 1) (Kuklina, 2010):

1) information-analytical (acquaintance with the educational material - professional terms, texts);

2) training and reproductive (developing the ability of the trainees to build their own statements based on previously learned linguistic and speech units);

3) productive-creative (active use of skills and abilities, formed at previous stages).

The model is graphically shown below (figure 1). 


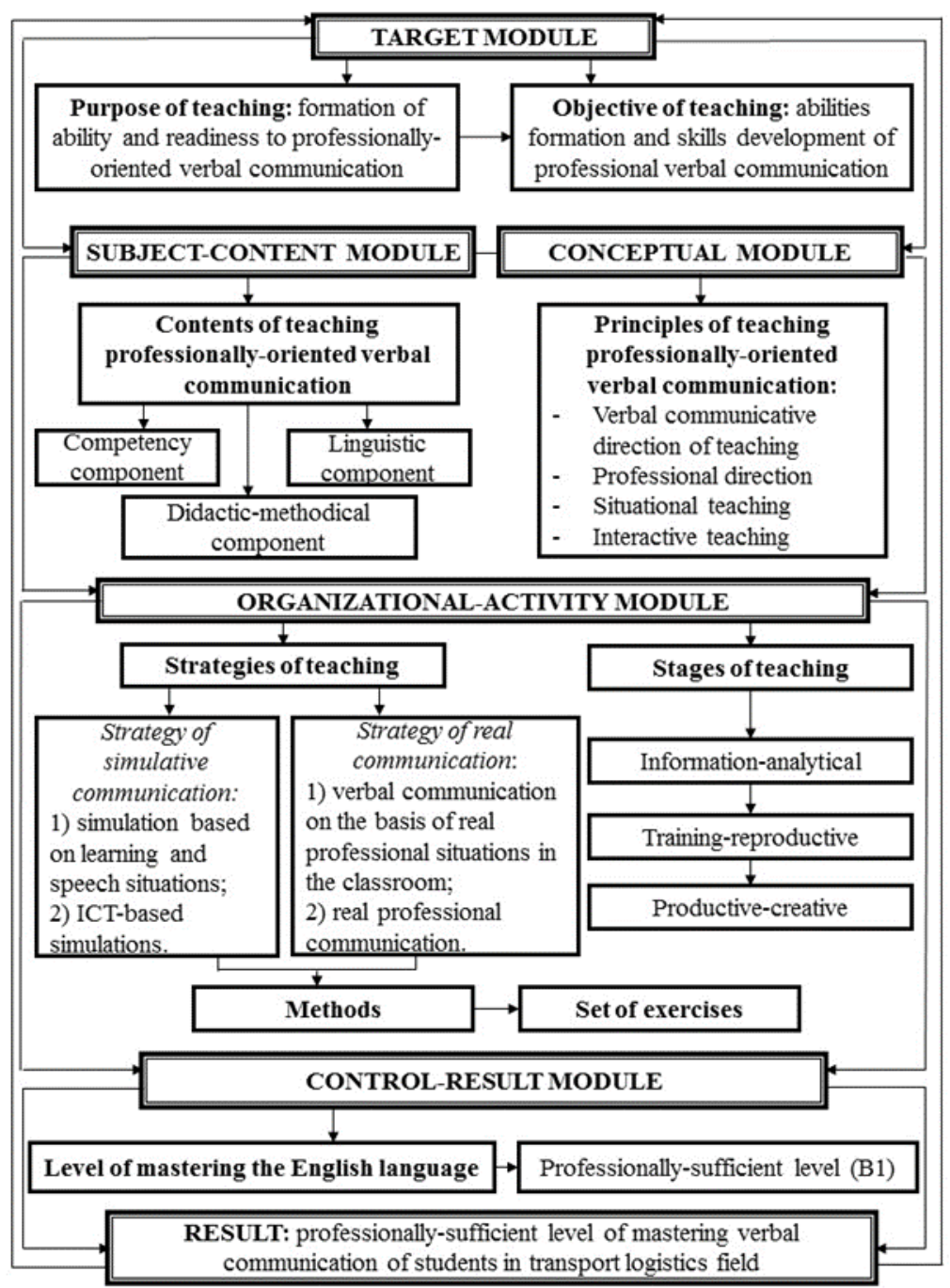

Figure: Integrative model of teaching professional verbal communication

\section{Materials and Methods}

\subsection{Research methods}

In order to answer research questions and test the hypothesis put forward, the following research methods are used: 1) theoretical: analysis and generalization of scientific literature on psychology, pedagogy, methods of teaching foreign languages; analysis of normative documentation; 2) empirical: questionnaire, pedagogical observation, interview, testing, experienced training; 3) statistical: processing of data from experienced training, graphical representation of results.

\subsection{Research Stages}

To implement the integrative model of teaching professionally-oriented verbal communication in English of students of transport specialties experienced teaching were conducted. We consider experimental teaching as one of the methods of scientific research.

Experimental teaching was conducted in three stages: 
I stage - preparatory (questionnaire, interviews with participants of the experimental training, diagnostic test);

II stage - experimental training, which includes a midline test;

III stage - final (final test, comparative analysis of experimental training, conclusions).

Each stage of experimental training consisted of a number of tasks.

The tasks of the preparatory stage:

- to reveal the degree of demand for interactive language teaching methods by university teachers;

- to reveal the attitude of the students to the study of the English language discipline;

- to determine the existing level of the formation of skills and abilities of professionally-oriented verbal communication of students.

The tasks of the experimental training:

- to form students' skills and abilities of professionally-oriented verbal communication;

- to reveal the degree of effectiveness of the developed model and the system of exercises.

The tasks of the final stage:

- to carry out statistical processing of the results;

- to analyze the data of experimental training;

- to summarize the theoretical and practical experience of studying the process of teaching professionally-oriented verbal communication in English of future transport workers.

\section{Results and Discussion}

The need to achieve this goal determined the structure of the experimental work, which was developed by us on the basis of the research of E.A. Shtulman (1971) and P.B. Gurvich (1980). Before the beginning of the experimental training, we conducted a survey of the English language teachers. Its purpose was: a) to identify the difficulties encountered in teaching professionally-oriented verbal communication of students; b) the attitude of teachers to the use of situations of professional verbal communication, ICT, interactive teaching methods (Mironova, 2008), contributing to the formation of skills and abilities of professionally-oriented verbal communication.

The results of the questionnaire, in which teachers took part, showed that only $30.4 \%$ of them regularly use ICT, not all use interactive methods, because teachers consider them labor-intensive, requiring a lot of time and effort to prepare and conduct. Those teachers who regularly or often use them $(27.3 \%)$ prefer discussion and conferences, as a rule, at the final stage of work on the topic. This is due to the fact that at the first and midline stages students still do not have speaking skills, there is no sufficient lexical and terminological base which causes difficulties in expressing thoughts in English.

The questionnaire conducted among the students showed that the students are interested in learning English in order to continue using it in their professional activities, teaching a foreign language should be professionally oriented, and the ability to communicate with foreign colleagues on professional topics is a priority in the students' wishes. 80 students (40 transport specialties and 40 other engineering specialties) were interviewed.

To determine the level of verbal speech (monologic and dialogical) students were asked to perform oral tasks: a) monologic statement; b) drawing up a dialogue on a given situation; c) information exchange. The level of the formation of the skills and abilities of professionally-oriented verbal communication was determined by the following parameters:

XLinguae, Volume 11, Issue 2, April 2018, ISSN 1337-8384, eISSN 2453-711X 
1) language accuracy (presence / absence of mistakes in pronunciation, grammatical, lexical);

2) volume of statements;

3) speech rate (number of syllables per 1 minute of speaking, presence / absence, and duration of pauses);

4) solving communicative task in a situation.

Based on this, we determined the following criteria for task 3:

1) language accuracy;

2) speech rate;

3) sequence of information;

4) information sufficiency.

Experimental training was organized with II year-students of three groups of the specialties "Transportation and traffic management, operation of transport", "Transport, transport equipment and technologies".

The diagnostic test, the purpose of which was: a) to obtain a general characteristic of the language training of students; b) determine the level of the formation of the skills of professionally-oriented verbal communication of students, consisted of three tasks.

\section{Table 2: Assessment criteria}

\begin{tabular}{|l|l|}
\hline Points & Assessment of answers \\
\hline 5 points & $\begin{array}{l}\text { received students whose monologic statements and dialogical speech } \\
\text { did not contain significant pronunciation, grammatical and lexical } \\
\text { mistakes }\end{array}$ \\
\hline 4 points & $1-2$ mistakes that do not distort the meaning of the statement \\
\hline 3 points & $3-4$ mistakes \\
\hline & Volume of the statement \\
\hline 5 points & 8 -10 words \\
\hline 3 points & $7-8$ words \\
\hline & Less than 7 words \\
\hline 5 points & Speech rate: \\
\hline 4 points & 150 syllables per 1 minute in speaking and more \\
\hline 3 points & Less than 130 words \\
\hline & Solving of verbal communicative task in a situation \\
\hline 5 points & complete implementation of the verbal communicative task \\
\hline 4 points & verbal communicative task is not fully implemented \\
\hline 3 points & verbal communicative task is not complete and inaccurate \\
\hline & Sequence of information (task 3) \\
\hline 5 points & $\begin{array}{l}\text { full compliance with the format of the message receiving / } \\
\text { transmission - the correct sequence of information delivery }\end{array}$ \\
\hline 4 points & $1-2$ inaccuracies \\
\hline 3 points & $3-4$ inaccuracies \\
\hline & Information sufficiency (task 3) \\
\hline 5 points & information has been transferred in full \\
\hline 4 points & one of the message components is missing \\
\hline 2 points & missing two components \\
\hline & $\begin{array}{l}\text { on the indicators considered above, in all three assignments, the } \\
\text { students were obtained whose result was below the permissible norm }\end{array}$ \\
\hline
\end{tabular}

The average score was calculated by the following formula:

En x X1 
En - number of students who received a certain point;

$\mathrm{X} 1$ - points;

$\mathrm{N}$ - number of students in a group.

Percentage of average score to the top point of "5" (100\%) we calculated by the following formula:

$\mathrm{X} \times 100 \%$
$\mathrm{n} \%=-\mathrm{5}$
$\mathrm{X}-$ average score

Table 3: Results of the monologic statement (diagnostic test)

\begin{tabular}{|c|c|c|c|c|c|c|c|c|c|c|c|c|c|}
\hline Criteria & $\exists$ & $\stackrel{\text { I }}{\rightarrow}$ & $\stackrel{?}{-}$ & $\stackrel{+}{-}$ & $\stackrel{n}{2}$ & $\stackrel{0}{\circ}$ & I & $\stackrel{\infty}{-}$ & 9 & $\stackrel{0}{\varrho}$ & $\exists$ & $\cong$ & $\stackrel{m}{=}$ \\
\hline $\begin{array}{l}\text { Language } \\
\text { accuracy }\end{array}$ & 4 & 3 & 4 & 2 & 4 & 3 & 5 & 3 & 2 & 3 & 5 & 5 & 4 \\
\hline $\begin{array}{l}\text { Volume } \\
\text { statement }\end{array}$ & 4 & 3 & 3 & 3 & 4 & 3 & 4 & 4 & 3 & 4 & 4 & 4 & 3 \\
\hline Speech rate & 3 & 3 & 4 & 3 & 4 & 3 & 4 & 4 & 3 & 3 & 4 & 4 & 4 \\
\hline $\begin{array}{l}\text { Solving } \\
\text { communicativ } \\
\text { e verbal task } \\
\text { in a situation }\end{array}$ & 3 & 3 & 4 & 3 & 4 & 3 & 4 & 3 & 3 & 4 & 5 & 4 & 3 \\
\hline
\end{tabular}

From the table 3 we see that at the stage of the diagnostic test the students showed a low result in the task of determining the level of formation of skills and abilities in monologic speech. The average scores for the designated indicators are as follows:

-language accuracy: from 3,33 to $3,85(66,6 \%$ and $77 \%$ hence, the relative higher score);

- volume of the statement: from 3,53 to $3,83(70,6 \%-76,6 \%)$;

- speech rate: from 3,5 to $3,71(70 \%-74,2 \%)$;

- solving verbal communicative tasks in situations: from 3,41 to $3,71(68,2 \%$ $74,2 \%)$.

Analysis of the results obtained on the basis of the diagnostic test, determining the level of the formation of skills and abilities of dialogical and monologic speeches testify to the low level of the formation of skills and abilities in the aspects considered by the majority of students.

The next stage was experimental training, which was built on the basis of the developed system of exercises. The following materials were used as educational material: 1) the supplementary to the basic teaching methodical manual for the students of the II course of specialties "Organization of transport, transport and operation of transport" and "Transport, transport equipment and technologies", developed by us, which contains text based content with learning and speech situations, on topics identified in the training program for these specialties.

The average scores for task 1 in midline test changed as follows:

- language accuracy: from 3,5 to $4,07(70 \%$ - $81,4 \%)$ - minimum score $+3,4 \%$, maximum score $+4,4 \%$;

- volume of the statement: from 3,69 to $3,91(73,8 \%-78,2 \%)$ - minimum score + $2,6 \%$, maximum score $+1,6 \%$;

- speech rate: from 3,56 to $3,79-(71,2 \%,-75,8 \%)$ - minimum score $+1,2 \%$, maximum score $+1,6 \%$;

- solving verbal communicative task in a situation: from 3,67 to $3,88(73,4 \%-77,6 \%)$

- minimum score $+5,2 \%$, maximum score $+3 ; 0 \%$. 
The analysis of the obtained results made it possible to draw the following conclusions:

1) positive dynamics is observed for all indicators in each of the tasks;

2) the highest changes occurred in the indicators "information sufficiency" (task 3) and "language accuracy" (task 2);

3 ) the average volume of the statement and the speech rate of the students did not change significantly;

4) the solution of the verbal communicative task has improved to a greater extent in the monologic statement.

After the end of the experimental training in groups, the final stage was conducted to determine the degree of formation of skills and abilities of professionally-oriented verbal communication based on the application of the proposed model and testing the effectiveness of the developed methodology. The tasks at this stage were similar to those of the diagnostic and midline tests and were compiled in accordance with the topics studied in the second year.

Table 4. Results of the monologic statement (final test).

\begin{tabular}{|c|c|c|c|c|c|c|c|c|c|c|c|c|c|}
\hline Criteria & 二 & $\stackrel{\sim}{-}$ & $\stackrel{n}{n}$ & $\stackrel{+}{\sim}$ & $\stackrel{n}{n}$ & $\stackrel{0}{-}$ & $\Xi$ & $\stackrel{\infty}{-}$ & $\stackrel{9}{-}$ & $\stackrel{0}{=}$ & $\exists$ & $\stackrel{\simeq}{\leftrightarrows}$ & $=$ \\
\hline $\begin{array}{l}\text { Language } \\
\text { accuracy }\end{array}$ & 5 & 4 & 4 & 3 & 5 & 4 & 5 & 4 & 3 & 4 & 5 & 5 & 4 \\
\hline $\begin{array}{l}\begin{array}{l}\text { Volume } \\
\text { statement }\end{array} \\
\end{array}$ & 4 & 4 & 4 & 4 & 4 & 3 & 4 & 4 & 3 & 4 & 5 & 5 & 4 \\
\hline Speech rate & 4 & 3 & 4 & 3 & 4 & 4 & 5 & 4 & 4 & 4 & 5 & 4 & 4 \\
\hline $\begin{array}{l}\text { Solving } \\
\text { communicat } \\
\text { ive verbal } \\
\text { task in a } \\
\text { situation }\end{array}$ & 4 & 4 & 4 & 3 & 5 & 3 & 5 & 4 & 3 & 5 & 5 & 5 & 4 \\
\hline
\end{tabular}

The figures in the table 4 indicate positive dynamics in all indicators. The average score (in comparison with the results of the diagnostic test) has changed as follows:

- language accuracy: from 3,88 to $4,29(77, \% 6-88,8 \%)$ - minimum score $+11,0 \%$, maximum score $+8,5 \%$;

- volume of the statement: from 3,81 to $4,5(76,2 \%$ - 90\%) - minimum score $+5,2 \%$, maximum score $+13,4 \%$;

- speech race: from 3,67 to $4,0(73,4 \%-80 \%)$ - minimum score $+3,4 \%$, maximum score $+4,4 \%$;

- solving verbal communicative task in a situation: from 3,88 to $4,21(77,6 \%-84,2 \%)$

- minimum score $+9,4 \%$, maximum score $+10 \%$.

Changes in the indicators for all sections in the groups are shown in the Figure 2. 


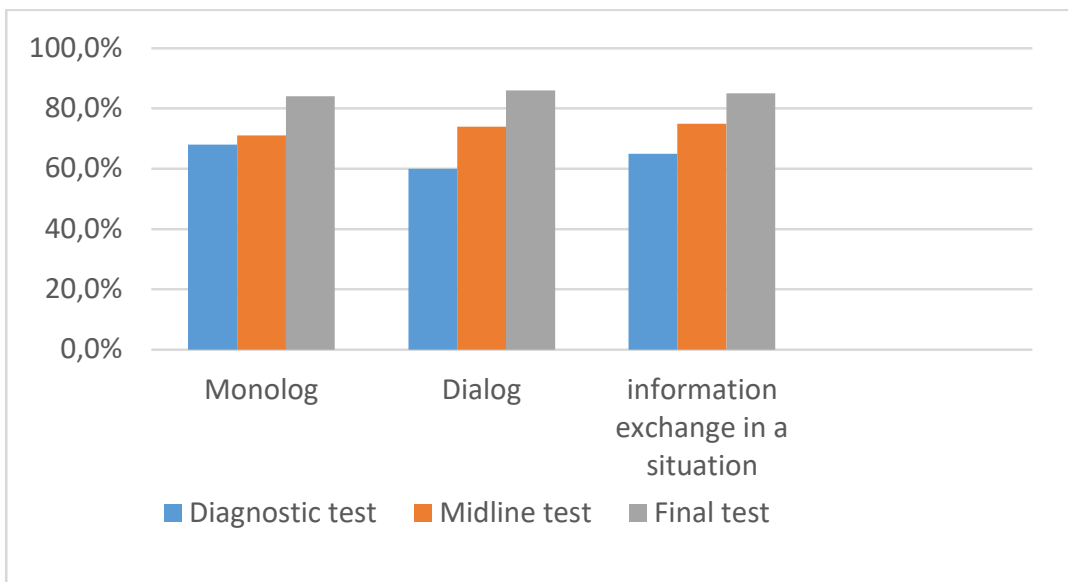

Figure 2: Change in the success rate in monologic statement, dialogical speech and information exchange in a situation

Comparison of the results of the diagnostic and final tests allowed us to state the following:

1) speech of the students became more literate;

2) statements became more voluminous, the vocabulary increased;

3) rate of speech increased, the duration of pauses was reduced;

4) informative saturation of monologic statements and exchanges of dialogue increased;

5) students acquired the skills of information exchange, following the procedure for sending and receiving messages according to the required situations.

Thus, the analysis of the results of experienced training confirmed his hypothesis: the training of professionally-oriented communication in English for students of transport specialties is effective if it is carried out in accordance with the developed model and the system of exercises on the basis of a methodical manual compiled with the requirements of knowledge of English.

\section{Conclusion}

Professional verbal communication in English is established as a means of speech and production interaction of transport workers. The content of training to communicate verbally in a foreign language corresponds to the requirements of the future profession, the context of the professional activity. The professionally-oriented communicative competence of the student is formed on the basis of the goals of teaching foreign languages, as well as principles and methods of teaching that we proved and on the components of the communicative competence of teaching professionally-oriented verbal speech in English classes. These same specific features of teaching professionally-oriented verbal speech in English classes are the constituent elements of the created integrative model of teaching professionallyoriented verbal speech. The methodology of teaching professionally-oriented verbal communication of students of transport specialties is developed, which includes: a) stages of work on foreign professional verbal communication; b) the principles of work on this type of speech activity; c) strategies and methods of teaching; d) the system of exercises; e) a measuring device for determining the level of formation of the skills and abilities of professional verbal communication of students. This

XLinguae, Volume 11, Issue 2, April 2018, ISSN 1337-8384, eISSN 2453-711X 
methodology based on the model allowed to optimize the traditional system of teaching the language of future transport specialists.

In experimental training, the hypothesis of the study was confirmed. Training for professionally-oriented verbal communication of students of transport specialties is always successful and effective, in accordance with certain conditions. The conditions are related to: a) the specificity of professional activity and its reflection by means of the language being studied; b) the presence of a rationally selected professionalsubjective aspect in the content of training (special vocabulary, topics, texts of professional orientation, and most importantly, situations of professional verbal communication); c) using a system of exercises of a professional orientation; d) the presence of a modeled educational foreign-language environment created in specialized laboratories and using simulators.

Work on the formation of skills and abilities of professionally-oriented communication was carried out on the basis of the developed system of exercises. Each stage plays a role in the formation of skills and abilities of professionallyoriented verbal communication. The developed integrative model of professional verbal communication is suitable for the specialty of transport, and the volume of exercises was prepared for half a year in order to achieve a professionally-sufficient level (B1). The theoretical and practical research carried out confirmed the effectiveness of the model and methods of teaching professionally-oriented verbal communication in English for students of transport specialties, thereby answering the questions posed to the study.

\section{Bibliographic references}

AGBATOGUN, A.O. 2014. Developing Learners' Second Language Communicative Competence through Active Learning. In: Technology \& Society, vol. 17, n. 2, pp. 257-269. ISSN 1436-4522

ARHANGELSKY, S.I. 1980. The educational process in the higher school, its logical foundations and methods: Teaching-methodical manual. Moscow: Vysshaya shkola.

ARPABEKOV, M.I. - SULEIMENOV, T.B. 2012. Transport logistics. Astana: Foliant. ISBN 978-601-601-7400-31-6

AZIMOV, E.G. - SHUKIN, A.N. 2009. A new dictionary of methodological terms and notions. Moscow: Ikar Publ. ISBN 978-5-7974-0207-7.

BIROVA, J. - VASBIEVA, D.G. - MASALIMOVA, A.R. 2017. Communication in French foreign language learning by implementing the aspects of interculturality. In: Communications - Scientific Letters of the University of Zilina, vol.19, n. 4, pp. 95104. ISSN:1335-4205.

BOGATYREVA, M.A. 1997. To the problem of distinguishing the levels of professional knowledge of a foreign language. In: Foreign languages at school, vol. 1, n. 2, pp. 28-33. ISBN: 0-16-011294-X ISSN: 8755-0393

CAÑADO, M.L.P. 2013. Competency-based Language Teaching in Higher Education. In: Educational Linguistics, vol. 14, pp.191-105. ISSN 1572-0292

ELUKHINA, N.V. 1995. Oral communication at the lesson, means and ways of its management. Foreign languages at school. Moscow: Prosveshenie. ISSN 0130-6073

FAHRUTDINOV, A.R. - FAHRUTDINOV, R. - YUSUPOV R. 2016. The Model of Forming Communicative Competence of Students in the Process of Teaching the English Language. In: International Journal of Environmental \& Science Education, vol. 11, n. 6, pp. 1285-1294 e-ISSN: 1306-3065

GALSKOVA, N.D. 2004. Theory of teaching foreign languages. Moscow: Publ.center «Akademia». ISBN 978-5-7695-3059-3 
GALUSHKIN, A.A. 2017a. Operational management of enterprise structures in the sphere of education and science: Problems and methods for their solution. In: European Research Studies Journal, vol. 20, n. 4, pp. 412-420. ISSN: 11082976.

GALUSHKIN, A.A. 2017b. Organizations of the sphere of education and science methods of competitiveness improvement. In: European Research Studies Journal, vol. 20, n. 4B, pp. 421-431. ISSN: 11082976.

GEZ, N.E. 1985. Formation of communicative competence as an object of foreign methodical research. In: Foreign languages at school, n. 2, pp. 17-24. ISSN 01306073

GRIFFITHS, C. 2011. Intercultural Communicative Competence. In: English Language and Literature Studies, vol. 1, n. 2, pp.113-122. ISSN 1925-4768

GURVICH, P.B. 1980. Theory and practice of the experiment in methodics of teaching foreign languages. Vladimir: VSU. ISBN 978-5-93907-083-6

HYMES, D. 1991. On Communicative Competence. Philadelphia: University of Pennsylvania. ISBN: 0894950584

KAVANAGH, M. 2007. English for the Automobile Industry. Oxford: Oxford University press. ISBN 978-0-19-457900-1

KNOWLES, M. - HOLTON, E. - SWANSON, R. 2005. The Adult Learner: The Definitive Classic in Adult Education and Human Resource Development. New York: Elsevier. ISBN 978-0408106979 6

KOSOGOVA, A.S. 2014. Modeling in Education. Irkutsk: ISU. ISBN 978-5-85827788-0

KUKLINA, C.G. 2010. Approaches and strategies of foreign-language education in the secondary school. N. Novgorod: N.A. Dobrolyubova NSLU. ISSN 2410-3101

KUNANBAYEVA, S.S. 2016. Educational Paradigm: Implementation of the Competence-Based Approach to the Higher School System. In: International Journal of Environmental \& Science Education, vol. 11, n. 18, pp. 12699-12710. e-ISSN: 1306-3065

LEONTYEV, A.A. 2003. Language and speech activity of general and pedagogical psychology: Selected psychological papers. Moscow: Moscow psychological social institute. Voronezh: "Modek". ISBN 5-89395-497-1

LI, N. - PYRKOVA, K.V. - RYABOVA, T.V. 2017. Teaching Communication Skills and Decision-Making to University Students. In: EURASIA Journal of Mathematics, Science and Technology Education, vol. 13, n. 8, pp. 4715-4723. ISSN: $13058215,13058223$.

LITON, H.A. 2015. ESP Learners' Needs Related Learning for the Workplace. In: International Journal of Instruction, vol. 8, n. 2. pp. 3-16. e-ISSN: 1308-1470

MAKAR, L.V. 2000. Teaching of professionally-oriented communication in the English language of students of non-linguistic high school. extended abstract: $\mathrm{PhD}$ Thesis. St. Petersburg: Peter.

MAKULOVA, A.T. - ALIMZHANOVA, G.M. - BEKTURGANOVA, Zh.M. 2015. Theory and Practice of Competency-Based Approach in Education International Education Studies. In: Canadian Center of Science and Education, vol. 8, n. 8. pp.183192. ISSN 1913-9020 E-ISSN 1913-9039

MALINAUSKAS, R.K. 2017, Enhancing of Self-Efficacy in Teacher Education Students European Journal of Contemporary Education, vol. 6, n. 4, pp. 732-738. DOI: 10.13187/ejced.2017.4.732

MASALIMOVA, A.R. - IVANOV, V.G. 2016. Formation of Graduates' Professional Competence in Terms of Interaction Between Educational Environment and Production. In: International journal of environmental \& scientific education, vol. 11, n. 9, pp. 2735-2743. ISSN: 1306-3065

XLinguae, Volume 11, Issue 2, April 2018, ISSN 1337-8384, eISSN 2453-711X 
MIRONOVA, I.A. 2008. Formation of Intercultural competence of students in the process of teaching foreign-language professional-oriented communication: $\mathrm{PhD}$ Thesis. St. Petersburg: Peter.

PASSOV, E.I. 1991. Communicative method of teaching foreign-language speaking. Moscow: Prosveshenie. ISBN 5-09-000707-1-0-16

PASSOV, E.I. - STOYANOVSKY, A.M. 1989. Situation of speech communication as a methodic category. In: Foreign languages at school, n. 2, pp.18-22. ISSN 01306073

ROGOVA, G.V. 1984. The role of learning situation in teaching the foreign language. In: Foreign languages at school. n. 4, pp. 60-64. ISSN 0130-6073

SHTULMAN, E.A. 1971. Basics of the experiment in teaching foreign languages. Voronezh: Publ. of Voronezh university. ISBN 5-7455-0195-2

STUKALINA, Y. 2014. Professional English for students of logistics. Riga: Transport and Telecommunication Institute. ISBN 978-9984-818-67-2

TEMNIKOVA, V.L. - OSIYANOVA, O.M. - TUCHKOVA, E.Y. 2016. Communication Situations as a Means of Verbal Communication Culture Formation in Foreign Language Learning Indian. In: Journal of Science and Technology, vol. 9, n. 16, pp. 1-5. ISSN: 0974-5645

TYUNNIKOV, Y.S. 2017, Classification of Innovation Objectives set for Continuing Professional Teacher Development. European Journal of Contemporary Education, vol. 6 n. 1: pp. 167-181. DOI: 10.13187/ejced.2017.1.167

VAISBURD, M.L. 2001. Using learning speech situations in teaching oral speech in the foreign language. Obninsk: Titul. ISBN 5-86866-158-3

ZIMNYAYA, I.A. 1985. Psychological aspects of teaching speaking in a foreign language. Moscow: Prosveshenie. ISBN 5-85880-390-3

ZIMNYAYA, I.A. 2004. Key competences as the effective-target basis of competence approach in education. Author's version. Moscow: Research Center for Quality Problems in Training Specialists. ISBN 5-7563-0339-1

Words: 6605

Characters: 45210 (25,12 standard pages)

Assoc. prof. Aigul Y. Niyazova, PhD

Department of Theory and Practice of Foreign Languages

L.N. Gumilyov Eurasian National University

11 Kazhymukan Str.

010000 Astana

Republic of Kazakhstan

naigul73@mail.ru

Master student Alma K. Mussagozhina

Department of Theory and Practice of Foreign Languages

L.N. Gumilyov Eurasian National University

11 Kazhymukan Str.

010000 Astana

Republic of Kazakhstan

kz.almazhan@mail.ru

Master student Ayazhan B. Kabdenova

Department of Theory and Practice of Foreign Languages

L.N. Gumilyov Eurasian National University

11 Kazhymukan Str.

010000 Astana

Republic of Kazakhstan 
kabdenova_aika@mail.ru

Master student Assylzada E. Lukpanova

Department of Theory and Practice of Foreign Languages

L.N. Gumilyov Eurasian National University

11 Kazhymukan Str.

010000 Astana

Republic of Kazakhstan

asilzada0494@mail.ru

Assoc. prof. Madina T. Kozhakanova, PhD

Department of Theory and Practice of Foreign Languages

L.N. Gumilyov Eurasian National University

11 Kazhymukan Str.

010000 Astana

Republic of Kazakhstan

modi_85@mail.ru 